DOI: 10.17707/AgricultForest.62.3.06

\author{
Atefeh BEHZADFAR, Augusto CÉSAR FERREIRA GUIÇARDI, \\ Mile MARKOSKI, Natanael RODOLFO RIBEIRO SAKUNO, \\ Ronaldo LUIZ MINCATO, Milena MOTEVA \\ and Vjekoslav TANASKOVIK ${ }^{* 1}$
}

\title{
CALCULATION OF SOIL LOSS FROM THE S7-3 CATCHMENT OF THE SHIRINDAREH WATERSHED, IRAN USING THE RIVER BASIN MODEL
}

\begin{abstract}
SUMMARY
Soil erosion is one of the major environmental problems in Iran. Factors such as soil erodibility, density of the river network of the river basin and its asymmetry, slope length and steepness, agricultural practices and the other physical-geographical characteristics, were surveyed and soil loss rate were calculated using an empirical River Basin Model (RBM). The objective of this research was to introduce a new method based on Erosion Potential Method (EPM) for the estimation of soil erosion on the catchment scale. Calculated peak discharge from the river basin was $35 \mathrm{~m}^{3} \mathrm{~s}^{-1}$ for the incidence of 100 years and the net soil loss was $3182 \mathrm{~m}^{3} \mathrm{yr}^{-1}$, specific $164 \mathrm{~m}^{3} \mathrm{~km}^{-2} \mathrm{yr}^{-1}$. Supplementary research is needed to address model limitations regarding the further development in relation to the GIS adaptations.

Key words: Soil erosion, River Basin Model, Sediment yield, Shirindareh watershed.

\section{INTRODUCTION}

Soil degradation caused by erosion, as one of the most important environmental problems in the world (Stoffel and Huggel, 2012) and sediment transport is not only the cause of an imbalance of natural rivers and streams, but also the cause of change in the river channel and sediment accumulation behind dams reducing their storage volumes (Sadeghi et al., 2014).

Soil loss is a serious ecological concern in various environments worldwide (Kisic et al., 2016; Ballesteros-Cánovas et al., 2015; Ristic et al., 2001, Curovic et al., 1999). Sediments are responsible for transporting a significant fraction of nutrients and contaminants. Large suspended sediment fluxes in river catchments, which result from soil loss due to water erosion, constitute a major environmental issue (Louvat et al., 2008), heavily affecting

\footnotetext{
${ }^{1}$ Atefeh Behzadfar, Azad University, Science and Research Branch, Tehran, IRAN; Augusto César Ferreira Guiçardi, Natanael Rodolfo Ribeiro Sakuno, Ronaldo Luiz Mincato, Universidade Federal de Alfenas, Programa de Pós-Graduação - Ciências Ambientais, BRAZIL; Milena Moteva, University of Architecture, Civil Engineering and Geodesy, Faculty of Geodesy, Department of Land Management and Agrarian Development, BULGARIA; Mile Markoski, Vjekoslav Sciences and Food, University Ss. Cyril and Methodius in Skopje, MACEDONIA.

Notes: The authors declare that they have no conflicts of interest. Authorship Form signed online.
} Tanaskovik (*corresponding author: vjekoslavtanaskovic@yahoo.com), Faculty of Agricultural
\end{abstract}


sustainable land management in various environments (Ballesteros - Cánovas et al, 2015; Stoffel et al, 2013).

Study of soil erosion and sediment yield is one of the basic necessities to achieve integrated land management and soil and water conservation (Khaledi Darvishan et al., 2014).

Direct measurements of erosion in the catchment are valid for a number of year's measurements of solid transport in the closing-section (Behzadfar et al., 2014a and Behzadfar et al., 2014b). The water and sediment sampling in given intervals need a lot of time and is costly (Khaledi Darvishan et al., 2010) and the assessment of sediment yield using soil erosion models have been used more and more (Spalevic et al., 2013a, 2013b, 2013c).

The modelling of the erosion process has progressed rapidly and a variety of models have been developed to predict both runoff and soil loss. We used the computer-graphic "River Basin" model (Spalevic, 2011; Spalevic et al., 2000; Spalevic, 1999) for prediction of soil erosion intensity from the watershed area.

The objectives of this research were to quantify the sediment yield in the studied S7-3 Watershed of the Shirindareh River Basin testing the possibility of application of the River Basin model in the conditions of the Caspian Sea Watersheds.

\section{MATERIAL AND METHODS}

We calculated soil loss from the S7-3 Catchment $\left(19 \mathrm{~km}^{2}\right)$, of the Shirindareh Watershed, a tributary of the river Atrak (Caspian Sea Watershed), located in the north eastern parts of the mountainous area of Iran (Figure 1).
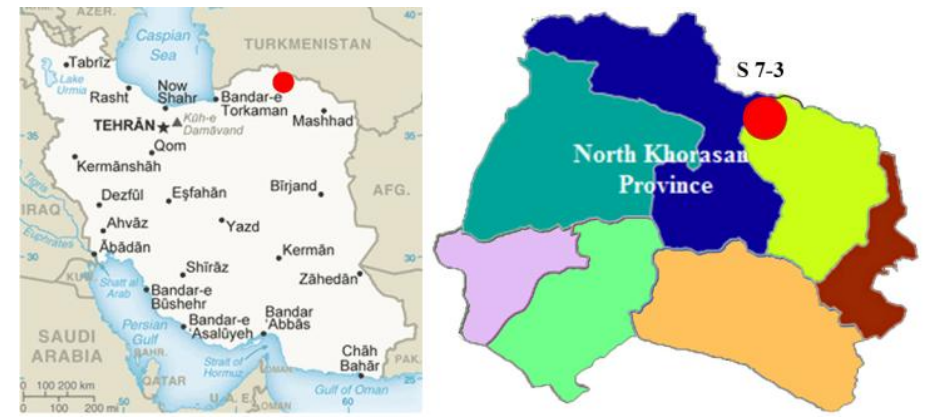

Figure 1. Study area of the S7-3 Catchment of the Shirindareh River Basin

Morphometric methods were used to determine the slope, the specific lengths, the exposition and form of the slopes, the depth of the erosion base and the density of erosion rills. Google Earth and Google Maps were used for further studying of the morphology of the features.

We used available data on Soils and of Geology of North Khorasan province, based on the research of the National Geological Survey Organization (Bolourchi, 1987).

Climatological data were received from the meteorological stations located in North Khorasan province of Iran. We analysed torrential rains, annual air temperatures, and average annual precipitations. 
Directly observing of large-scale hydrological processes is difficult. Modelling has become a key research tool at the basin scale studies (Fu et al., 2011).

The "River Basin" "physically-based model (Spalevic et al., 2000) as a computer-graphic catchment-scale hydrological model, with the Erosion Potential Method - EPM (Gavrilovic, 1972) rooted in the procedure of this model, was used for soil loss calculation from the studied watershed.

According to the method sediment yield is calculated using the following calculation:

$$
W_{y r}=T \cdot H_{y r} \cdot \pi \cdot \sqrt{ } Z^{3} \cdot F
$$

where $\mathrm{W}_{\mathrm{yr}}$ is the annual erosion in $\mathrm{m}^{3} \mathrm{yr}^{-1} ; \mathrm{T}$, the temperature coefficient; $\mathrm{H}_{\mathrm{yr}}$, the average yearly precipitation in $\mathrm{mm} ; \mathrm{Z}$, the erosion coefficient.

The erosion coefficient, $\mathrm{Z}$, was calculated as follows:

$$
Z=Y \cdot X \cdot(\phi+\sqrt{ } I)
$$

where, $\mathrm{Y}$ is Soil erodibility coefficient; $\mathrm{X}$ is Soil protection coefficient; $\phi$ is Erosion development coefficient (tables for $\mathrm{Y}, \mathrm{X}$ and $\phi$ coefficients available at Gavrilovic, 1972). $\mathrm{F}$ is the watershed area in $\mathrm{km}^{2}$.

The actual sediment yield was calculated as follows:

$$
G_{y r}=W_{y r} \cdot R_{u}
$$

where, $\mathrm{G}_{\mathrm{yr}}$ is the sediment yield in $\mathrm{m}^{3} \mathrm{yr}^{-1} ; \mathrm{W}_{\mathrm{yr}}$, the total annual erosion in $\mathrm{m}^{3} \mathrm{yr}^{-1}$; $\mathrm{R}_{\mathrm{u}}$ is sediment delivery ratio.

The actual sediment yield was calculated as follows:

$$
R_{u}=\frac{(\sqrt{O \cdot D})}{0.2 \cdot(L+10)}
$$

where, $\mathrm{O}$ is perimeter of the watershed in $\mathrm{km}$; $\mathrm{D}$ is the average difference of elevation of the watershed in $\mathrm{km}$; $\mathrm{L}$ is length of the catchment in $\mathrm{km}$.

\section{RESULTS AND DISCUSSION}

The climate of the studied area is continental, with the absolute maximum temperature of $34.6^{\circ} \mathrm{C}$ and the negative of $-24.4^{\circ} \mathrm{C}$, respectively. Average annual air temperature, $\mathrm{t} 0$, is $11.8^{\circ} \mathrm{C}$ and the Temperature coefficient of the region, $\mathrm{T}$, is calculated on 1.13; The amount of torrential rain, hb, on $33.53 \mathrm{~mm}$. The average annual precipitation, $\mathrm{H}_{\mathrm{yr}}$, is $303.2 \mathrm{~mm}$ (Source: Data from the North Khorasan Meteorological stations of Iran).

The coefficient of the river basin planning is calculated on 0.7 . The coefficient of the vegetation cover is calculated on 0.8 .

(A)symmetry coefficient indicates that there is a possibility for large flood waves to appear in the river basin. The value of $\mathrm{G}$ coefficient of 1.85 indicates

\footnotetext{
${ }^{2}$ Link to the "River Basin" exe file: www.agricultforest.ac.me/Spalevic/River
} 
there is high density of the hydrographic network. The value of $23.51 \%$ indicates that in the river basin prevail steep slopes.

According to the erosion type, it is mixed erosion. Surface erosion is the most pronounced on the steep slopes without vegetation cover. In the studied river basin some problems of overgrazing and livestock traces are recorded also.

Calculation of Sediment yield of the S7-3 Watershed of the Shirindareh River Basin of Iran is presented at the "River Basin" Report 1.

Report 1. The "River Basin" report for the S7-3 Watershed

Inputs: River basin area, $\boldsymbol{F}, 19.33 \mathrm{~km}^{2}$; The length of the watershed, $\boldsymbol{O}, 24.76, \mathrm{~km}$; Natural length of the main watercourse, $\mathbf{L v}, 12 \mathrm{~km}$; The shortest distance between the fountainhead and mouth, $\mathbf{L m}, 10.96 \mathrm{~km}$; The total length of the main watercourse with tributaries of I and II class, $\boldsymbol{\Sigma} \boldsymbol{L}, 35.67 \mathrm{~km}$; The area of the bigger river basin part, $\boldsymbol{F v}, 10.58 \mathrm{~km}^{2}$; The area of the smaller river basin part, $\boldsymbol{F m}, 8.75 \mathrm{~km}^{2}$; Altitude of the first contour line, h0, $1200 \mathrm{~m}$; The lowest river basin elevation, Hmin, 1119 $\mathrm{m}$; The highest river basin elevation, $\boldsymbol{H}_{\max }, 1758 \mathrm{~m} ; \mathrm{A}$ part of the river basin consisted of a very permeable products from rocks (limestone, sand, gravel), $\boldsymbol{f}$, 0.08; A part of the river basin area consisted of medium permeable rocks (slates, marls, brownstone), fpp, 0.25; A part of the river basin consisted of poor water permeability rocks (heavy clay, compact eruptive), fo, 0.67; A part of the river basin under forests, $\boldsymbol{f} \boldsymbol{s}, 0$; A part of the river basin under grass, meadows, pastures and orchards, ft, 1; A part of the river basin under bare land, plough-land and ground without grass vegetation, $\boldsymbol{f g}, 0$; The volume of the torrent rain, $\boldsymbol{h b}, 33.53 \mathrm{~mm}$; Incidence, Up, 100 years; Average annual air temperature, to, $11.8{ }^{\circ} \mathrm{C}$; Average annual precipitation, $\boldsymbol{H}_{\boldsymbol{y}}, 303.2 \mathrm{~mm}$; Types of soil products and related types, $\boldsymbol{Y}, 1.1$; River basin planning, coefficient of the river basin planning, Xa, 0.7; Numeral equivalents of visible and clearly exposed erosion process, $\varphi, 0.64$.

Results: Coefficient of the river basin form, A, 0.4; Coefficient of the watershed development, $\boldsymbol{m}, 0.77$; Average river basin width, $\boldsymbol{B}, 2,41, \mathrm{~km}$; (A)symmetry of the river basin, a, 0.19; Density of the river network of the basin, $\boldsymbol{G}, 1,85$; Coefficient of the river basin tortuousness, $\boldsymbol{K}, 1,09$; Average river basin altitude, $\boldsymbol{H}_{\boldsymbol{s}}, 1316.28 \mathrm{~m}$; Average elevation difference of the river basin, $\boldsymbol{D}, 197.28 \mathrm{~m}$; Average river basin decline, $\boldsymbol{I}_{s r}, 23.51 \%$; Coefficient of the region's permeability, $\boldsymbol{S}_{\boldsymbol{1}}, 0.88$; Coefficient of the vegetation cover, $\boldsymbol{S}_{2}, 0.8$; Maximal outflow from the river basin, $\boldsymbol{Q}_{\max }, 34 \mathrm{~m}^{3} \mathrm{~s}^{-1}$; Production of erosion material in the river basin, $\boldsymbol{W}_{\boldsymbol{y}}, 15842 \mathrm{~m}^{3} \mathrm{yr}^{-1}$; Coefficient of the deposit retention, $\boldsymbol{R} \boldsymbol{u}, 0.201$; Real soil losses, $\boldsymbol{G}_{\boldsymbol{y}}, 3182, \mathrm{~m}^{3} \mathrm{yr}^{-1}$; Real soil losses per $\mathrm{km}^{2}, 164 \mathrm{~m}^{3} \mathrm{yr}^{-1} \mathrm{~km}^{-2}$.

This approach is also in use: Bosnia and Herzegovina, Brazil, Bulgaria, Croatia, Czech Republic, Italy, Macedonia, Montenegro, Morocco, Saudi Arabia, Serbia, South Africa and Slovenia (Al-Turki et al., 2015; Gazdic et al., 2015; Spalevic et al., 2015a, 2015b, 2015c, 2015d, 2015e, 2015f, 2015g, 2015h, 2015i, 2015k; Vujacic \& Spalevic, 2016; Kostadinov et al., 2014; Spalevic et al., 2014a, 2014b, 2014c). The provided methodology have been successfully used in Iran in the regions of Chamgardalan, Kasilian, Kermanshah, Razavi Khorasan (Spalevic et al., 2016; Draganic et al., 2015a; Draganic et al., 2015b; Behzadfar et al., 2015; Barovic \& Spalevic, 2015; Sadeghi, 2005) and other regions. 


\section{CONCLUSIONS}

Based on the calculation of sediment yield it can be revealed that:

- Production of erosion material in the river basin, $\mathbf{W}_{\mathbf{y r}}$, was $15842 \mathrm{~m}^{3} \mathrm{yr}^{-1}$;

- Calculated soil losses are $3182 \mathrm{~m}^{3} \mathrm{yr}^{-1}$ and specific soil losses were $164.66 \mathrm{~m}^{3} \mathrm{yr}^{-1} \mathrm{~km}^{-2}$;

- The peak discharge was calculated on $34 \mathrm{~m}^{3} \mathrm{~s}^{-1}$ (incidence $100 \mathrm{yr}$ ).

This study confirmed the findings of Barovic et al. (2015); Behzadfar et al., 2015, Zia Abadi \& Ahmadi (2011); as well as Amiri (2010) in possibility of implementing the "River Basin Model" for the other river basins similar to the the Shirindareh Watershed of Iran, when hydrological stations are missing. The model is a good tool for rapid assessment of erosion risk to support decisionmaking and policy development.

\section{ACKNOWLEDGMENTS}

Field work was carried out in 2014 and 2015, funded by the Natural Resources and Watershed Management Office, North Khorasan of Iran.

\section{REFERENCES}

Al-Turki, A.M., Ibrahim, H.M., Spalevic, V. (2015): Impact of land use changes on soil erosion intensity in Wadi Jazan watershed in southwestern Saudi Arabia. Agrosym 2015, Jahorina, Bosnia and Herzegovina; 10/2015.

Ballesteros-Cánovas, J.A., Czaika, B., Janecka, K., Lempa, M., Kaczka, R.J., Stoffel, M. (2015): Flash floods in the Tatra Mountain streams: Frequency and triggers. Science of the Total Environment 511: 639-648.

Barovic, G., Leandro Naves Silva, M., Veloso Gomes Batista, P., Vujacic, D., Soares Souza, W., Cesar Avanzi, J., Behzadfar M., Spalevic, V. (2015). Estimation of sediment vield using the IntErO model in the S1-5 Watershed of the Shirindareh River Basin, Iran. Agriculture and Forestry 61(3): 233-243

Barovic, G. and Spalevic, V. (2015). Calculation of runoff and soil erosion intensity in the Raklianska Rijeka Watershed. Polimlie, Montenegro. The 6th International Symposium Agrosym 2015, Jahorina, 15-18 October 2015, Bosnia and Herzegovina.

Behzadfar, M., Curovic, M., Simunic, I., Tanaskovik, V., Spalevic, V. (2015): Calculation of soil erosion intensity in the S5-2 Watershed of the Shirindareh River Basin, Iran. International Conference on Soil, Tirana, Albania; 5/2015.

Behzadfar, M., Djurovic, N., Simunic, I., Filipovic, M., and Spalevic, V. (2014a). Calculation of soil erosion intensity in the S1-6 Watershed of the Shirindareh River Basin, Iran. International Scientific conference: Challenges in modern agricultural production, December 11, 2014, Skopje, Macedonia.

Behzadfar, M. Tazioli, A., Vukelic-Shutoska, M., Simunic, I., and Spalevic, V. (2014b). Calculation of sediment yield in the S1-1 Watershed, Shirindareh Watershed, Iran. Agriculture and Forestry, 60 (4): 207-216.

Bolourchi, M., Mehr Parto, M., and Afsharharb, A. (1987). Geological quadrangle map of Iran no. J5 (Bojnurd sheet), scale 1:250,000, Geological Survey of Iran.

Curovic, M., Spalevic, V., Dubak D. and Dozic, S. (1999): Suggestion for anti erosion arrangement of compartment 17 form unit Rudo Polje - Kovren. Agriculture and Forestry, Vol. 45. (3-4): 5-23, Podgorica

Draganic, J., Drobniak, B., Campar, J., Bulaiic, B., Zajovic, V., Behzadfar, M., Spalevic, V. (2015a). Calculation of Sediment yield using the IntErO Model in the S1-3 Watershed of the ShirinDareh River Basin. Iran. 9th Congress of the Soil Science Society of Bosnia and Herzegovina. November 2015, Mostar, Bosnia and Herzegovina.

Draganic, J., Silva, M. L. N., Avanzi, C. J., Kisic, I., Spalevic, V. (2015b). Soil Loss Estimation using the IntErO Model in the S1-2 Watershed of the ShirinDareh 
River Basin, Iran. 9th Congress of the Soil Science Society of Bosnia and Herzegovina. November 2015, Mostar, Bosnia and Herzegovina.

Fu, B.J., Liang, D., Lu, N., (2011): Landscape ecology: coupling of pattern, process, and scale. Chin. Geogr. Sci. 21 (4), 385-391.

Gavrilovic, S., (1972). Inzeniering o buiicnim tokovima i eroziii. Izgradnia. Beograd.

Gazdic, M., Peiovic, S., Vila, D., Vuiacic, D., Barovic, G., Diurovic, N., Tanaskoviki, V.. Spalevic, V. (2015): Soil erosion in the Orahovacka Rijeka Watershed, Montenegro. Book of Proceedings. Sixth International Scientific Agricultural Symposium “Agrosym 2015”. p: 1425-1432. DOI: 10.7251/AGSY15051425G

Kisic, I., Bogunovic, I., Birkas, M., Jurisic, A., Spalevic, V. (2016): The Role of Tillage and Crops in the Existence of the Soil. Archives of Agronomy and Soil Science, p: 1-11; DOI: 10.1080/03650340.2016.1213815.

Khaledi Darvishan, A., Sadeghi, S.H.R., Homaee, M. and Arabkhedri, M. (2014): Measuring Sheet Erosion using Synthetic Color-Contrast Aggregates. Hydrological Processes, 28(15): 4463-4471.

Khaledi Darvishan, A., Sadeghi, S.H.R. and Gholami, L. (2010). Efficacy of Time-Area Method in Simulating Temporal Variation of Sediment Yield in Chehelgazi Watershed, Iran. Annals of Warsaw University of Life Sciences, 42(1): 51-60.

Kostadinov S, Zlatic M, Dragicevic S, Novkovic I, Kosanin O, Borisavlievic A, Lakicevic M, Mladian D. (2014). Anthropogenic influence on erosion intensity changes in the Rasina river watershed - Central Serbia. Fresenius Environmental Bulletin. 23(1a): 254-263.

Louvat, P., Gislason, S.R., Allegre, C.J. (2008): Chemical and mechanical erosion rates in Iceland as deduced from river dissolved and solid material. Am. J. Sci. 308, 679-726. http://dx.doi.org/10.2475/05.2008.02.

Sadeghi, S.H.R., Gholami, L., Khaledi Darvishan, A. and Saeidi, P. (2014): A Review of the Application of the MUSLE Model Worldwide. Hydrological Sciences Journal. 59 (1-2): 365-375.

Sadeghi, S.H.R. (2005). Semi-Detailed Technique for Soil Erosion Mapping Based on BLM and Satellite Image Applications. J. Agric. Sci. Technol. Vol. 7: 133-142.

Spalevic, V., Curovic, M., Barovic, G., Florijancic, T., Boskovic, I., Kisic, I. (2015a). Assessment of Sediment Yield in the Tronosa River Basin of Montenegro. The 9th International Symposium on Plant-Soil Interactions at Low pH. October 18-23, 2015, Dubrovnik, Croatia.

Spalevic, V., Curovic, M., Barovic, G., Vujacic, D., Tunguz, V., Djurovic, N. (2015b). Soil erosion in the River Basin of Provala, Montenegro. Agrosym 2015, Jahorina, Bosnia and Herzegovina; 10/2015.

Spalevic, V., Vujacic, D., Barovic, G., Simunic, I., Moteva, M. and Tanaskovik, V. (2015c). Soil erosion evaluation in the Rastocki Potok Watershed of Montenegro using the Erosion Potential Method. ISAF 2015, Faculty of Agricultural Sciences and Food - Skopje, 7-9 October, 2015, Ohrid, Macedonia.

Spalevic, V., Frankl, A., Nyssen, J. Curovic, M. and Djurovic, N. (2015d). Calculation of soil erosion intensity in the Sutivanska Rijeka Watershed of Montenegro using the IntErO model. 2nd International Symposium for Agriculture and Food - ISAF 2015, Faculty of Agricultural Sciences and Food - Skopje, 7-9 October, 2015, Ohrid, Macedonia.

Spalevic, V., Curovic, M., Barovic, G., Vujacic, D., Djurovic, N. (2015e). Soil erosion in the River Basin of Kisjele Vode, Montenegro. International conference: Land Quality and Landscape Processes, Keszthely, Hungary; 06/2015

Spalevic, V., Barovic, G., Vujacic, D., Bozovic, P., Kalac, I., Nyssen, J. (2015f). Assessment of soil erosion in the Susica River Basin, Berane Valley, Montenegro. International Conference on Soil, Tirana, Albania; 4-7 May, 2015.

Spalevic, V., Barovic, G., Mitrovic, M., Hodzic, R., Mihajlovic, G., Frankl, A. (2015g). Assessment of sediment yield using the Erosion Potential Method (EPM) in the Karlicica Watershed of Montenegro. International Conference on Soil, Tirana, Albania. 
Spalevic, V., Blinkov, I., Trendafilov, A., Mukaetov, D., Djekovic, V., Djurovic, N. (2015h). Soil erosion assessment using the EPM method: A case study of the Ramcina River Basin, Montenegro. International Conference on Soil, Tirana, Albania; 4-7 May, 2015.

Spalevic, V., Curovic, M., Vujacic, D., Barovic, G., Frankl, A., and Nyssen, J. (2015i). Assessment of soil erosion at the Brzava small watershed of Montenegro using the IntErO model. Geophysical Research Abstracts. Vol. 17, EGU2015-15007, 2015.

Spalevic, V. Curovic, M. Tanaskovic, V., Djurovic, N., Lenaerts, T. and Nyssen, J. (2015k). Application of the IntErO model for the assessment of the soil erosion intensity and runoff of the river basin Dragovo Vrelo, Montenegro (invited speaker). Balkan Agriculture Congress, 8-10 September 2014. Edirne. Turkey.

Spalevic, V., Radanovic, D., Behzadfar, M, Diekovic, V., Andielkovic, A., Milosevic, N. (2014a): Calculation of the sediment vield of the Trebacka Rijeka, Polimlje, Montenegro. Agriculture and Forestry, Vol. 60. Issue 1: 259-272.

Spalevic, V., Hübl, J., Hasenauer, H., and Curovic, M. (2014b): Calculation of soil erosion intensity in the Bosniak Watershed, Polimlie River Basin, Montenegro. In the Proceedings of the 5th International Symposium "Agrosym 2014", Jahorina, Bosnia and Herzegovina, p. 730-738.

Spalevic, V., Curovic, M., Billi, P., Fazzini, M. Frankl, A., and Nyssen, J. (2014c): Soil erosion in the Zim Potok Watershed, Polimlje River Basin, Montenegro. The 5th International Symposium “Agrosym 2014”, Jahorina, 23-26 October 2014, Bosnia and Herzegovina, $\mathrm{p}$ 739-747.

Spalevic, V., Curovic, M., Billi, P., Fazzini, M. Frankl, A., and Nyssen, J. (2014d). Soil erosion in the Zim Potok Watershed, Polimlje River Basin, Montenegro. Agrosym 2014, Jahorina, 23-26 October 2014, Bosnia and Herzegovina, p 739-747.

Spalevic, V., Djurovic, N., Mijovic, S., Vukelic-Sutoska, M., Curovic, M. (2013a): Soil Erosion Intensity and Runoff on the Djuricka River Basin (North of Montenegro). Malaysian Journal of Soil Science, Vol. 17: p.49-68.

Spalevic, V., Curovic, M. Tanaskovik, V., Oljaca, M., Djurovic, N. (2013b): The impact of land use on soil erosion and run-off in the Krivaja river basin in Montenegro. The First International Symposium on Agricultural Engineering, 4th - 6th October 2013, Belgrade-Zemun, Serbia, VI: 1-14.

Spalevic, V., Nyssen, J., Curovic, M., Lenaerts, T., Kerckhof, A., Annys, K. Van Den Branden, J., Frankl, A. (2013c): The impact of land use on soil erosion in the river basin Boljanska Rijeka in Montenegro. In proceeding of the 4th International Symposium “Agrosym 2013”. p. 54-63.

Spalevic, V. (2011): Impact of land use on runoff and soil erosion in Polimlje. Doctoral thesis, Faculty of Agriculture of the University of Belgrade, Serbia, p 1-260.

Spalevic, V., Dlabac, A., Spalevic, B., Fuštić, B., Popović, V. (2000). Application of Computer-Graphic Methods in Studying the Discharge and Soil Erosion Intensity - I Programme "River Basins". Agriculture and Forestry, 46 (1-2): 19-36.

Spalevic, V. (1999): Application of computer-graphic methods in the studies of draining out and intensities of ground erosion in the Berane valley. Master thesis. Faculty of Agriculture of the University of Belgrade. Serbia, p.1-131.

Stoffel, M., Corona, C., Ballesteros-Cánovas, J.A., Bodoque, J.M. (2013): Dating and quantification of erosion processes based on exposed roots. Earth-Science Reviews 123: 18-34.

Stoffel M. Huggel C. (2012): Effects of climate change on mass movements in mountain environments. Progress in Physical Geography 36, $421-439$.

Vujacic, D., Spalevic, V. (2016). Assessment of Runoff and Soil Erosion in the Radulicka Rijeka Watershed, Polimlje, Montenegro. Agriculture and Forestry, 62 (2): 283-292.

Zia Abadi, L., Ahmadi, H. (2011). Comparison of EPM and geomorphology methods for erosion and sediment yield assessment in Kasilian Watershed, Mazandaran Province, Iran. Desert, 16: 103-109. 